\title{
Quality Evaluation of Ethiopian 100\% Cotton Carded Ring Spun Yarn with Respect to USTER Standards
}

\author{
Biruk Fentahun Adamu (D), Desalegn Atalie ${ }^{(D)}$, and Erkihun Zelalem Liyew \\ Textile Engineering, Ethiopian Institute of Textile and Fashion Technology, Bahir Dar University, Bahir Dar, Ethiopia \\ Correspondence should be addressed to Biruk Fentahun Adamu; birukfentahun2009@gmail.com
}

Received 24 June 2021; Revised 28 October 2021; Accepted 10 November 2021; Published 24 November 2021

Academic Editor: Abdullah A. Kendoush

Copyright ( 92021 Biruk Fentahun Adamu et al. This is an open access article distributed under the Creative Commons Attribution License, which permits unrestricted use, distribution, and reproduction in any medium, provided the original work is properly cited.

\begin{abstract}
Yarn quality influences both fabric production processes efficiency and export market. One method used to gauge competitiveness of an industry is to study its product quality. The aim of this research work is to evaluate the quality of Ethiopian textile spinning mills' $100 \%$ cotton carded ring spun yarns in terms of its evenness (coefficient of mass variation, CVm), imperfections (thick and thin places, neps), and tensile properties with USTER Statistics 2018. Five spinning mills (B3, A0, A2, A4, and K3) of 15N, 20Ne, $25 \mathrm{Ne}, 30 \mathrm{Ne}, 35 \mathrm{Ne}$, and $40 \mathrm{Ne}$ nominal yarn counts have been selected for the study. The yarn evenness and imperfections were measured using USTER tester 5 and tensile using a STATIMAT tester. The USTER statistical results showed 20.3Ne (mill B3), $32 \mathrm{Ne}$ (mill A4), and $36.2 \mathrm{Ne}$ (mill A2) had better overall quality, respectively. It was observed that most selected spinning mills had low evenness, imperfections, yarn strength, and good yarn elongation. Tensile properties of A2 (32.85Ne and $36.2 \mathrm{Ne})$ had fallen under 5\% USTER statistics percentile which indicates excellent yarn strength. Generally, from studied mills, it was seen that $61.5 \%$ of cotton yarn CVm and thin places falls at above $95 \%$ and $15 \%$ of yarn tenacity falls at $\leq 5 \%$ of Uster statistical percentile.
\end{abstract}

\section{Introduction}

In recent years, textile industry has seen a major economy growth in developing countries. The Ethiopian government also has given priority to the textile and garment manufacturing sector starting from the last two decades to diversify the exports because it is environmentally suitable to grow cotton and there is cheap manpower. Ethiopia has a high potential to crop cotton and is producing and exporting part of its products to the international market. Now, existing textile mills in the country are almost based on cotton; however, the quality of raw material is not satisfying the growing demand [1].

The quality of yarn is determined by the constituent fibre properties that can be used to forecast partially the physical properties of yarn and the success of spinning [2]. 80\% of Ethiopian cotton yarn is sold primarily to the local or domestic market, and $20 \%$ of the yarn is to export markets [3]. The Ethiopian spinning mills produce three types of cotton yarn: combed, carded, and open end with the yarn count ranging from $10 \mathrm{~s}$ to $20 \mathrm{~s}$ on open end and up to $60 \mathrm{~s}$ count in the ring frame with the available technology [4].

The quality of yarn and the associated testing of those yarn properties will determine the yarn quality and are crucial to meet yarn requirements for subsequent fabric manufacturing and end product [5]. Spinning technique, machine parameters, operation stages, processing conditions, and the physical characteristics of fibre determine its processing behaviour, production efficiency, and final yarn and fabric quality [6]. The ring spinning system is considered a crucial process in producing yarns due to its flexibility and high quality of yarns produced which are considered by most yarn producers to have ideal structure and parameters [7].

In USTER statistics, a yarn whose all quality characteristics of USTER statistics mean values lie below $25 \%$ is referred as excellent-quality yarn that is made from an extremely expensive and special raw material. For improvement of the yarn's quality, the textile industry faced with many challenges in order to compete in a world class manufacturing program. For this, the benchmarks with 
USTER statistics assure the top values as reference points needed to correspond with the requirements of spinning processing and the fabric's appearance, but always by knowing the requirements of the customers [8].

The USTER corporation periodically issues a very comprehensive statistical analysis of worldwide data under the title USTER statistics [2]. The UUSTER statistics are the only global benchmarking tool based on the global collection and testing of fibre, sliver, roving, and yarn samples that have been produced in every part of the world. The statistics were first introduced in 1957 and are periodically updated. The UUSTER statistics are recognized throughout the global textile industry as an essential tool for comparing key characteristics along the entire yarn production chain, from raw fibre, sliver, roving, and yarn. Today, fibre purchasing and yarn development and trading would be virtually unthinkable without USTER Statistics. According to USTER statistics, the most widely used quality parameters for yarn are its evenness (coefficient of mass variation (CV), imperfections (thin places, thick places, and neps) and strength [8]. Yarn tensile properties are one of its most vital quality physical characteristics which determine the efficiency of yarn conversion into fabric and tensile properties of the final product. Yarn tensile properties include yarn breaking strength and extension or elongation at yarn break [5].

Ethiopia is a potential cotton manufacturer and exporter of cotton yarn to the international market, so its yarn quality must be evaluated and known with respect to worldwide benchmarks. In this research work, we evaluated the quality level of Ethiopian 100\% cotton ring spun yarn with UUSTER standard benchmarks and also compared with each other.

\section{Materials and Methods}

2.1. Materials. Thirteen $100 \%$ cotton carded ring spun yarn samples were collected from five textile spinning mills in Ethiopia. The mills were selected based on their age, high production capacity, wide range of yarn count, and location that can represent different regions of Ethiopia.

\subsection{Methods}

\subsubsection{Data Collection}

(1) Secondary Data. Secondary data for each mill such as number of ring and rotor spinning machines, production capacity, yarn count range, and material type (cotton or other fibre) were collected from all Ethiopian cotton processing spinning mills as seen in Table 1. Also, data related to cotton lint samples from the selected mills were collected (Table 2 gives the details of the cotton lint properties). As illustrated in Table 1, there are 18 active spinning factories in Ethiopia, and they produce short staple yarns for local and global market.

Table 2 shows cotton lint properties such as length, strength micronaire, and maturity processed by different spinning mills. The properties of cotton fibre have an influence on determining spinning performance but are alone not determinantal factors in final yarn quality parameters.
To produce high-quality ring spun yarns, fine and sufficient strength of fibres is necessary to endure spinning preparations and spinning processing [9]. Typical cotton fibre quality parameters are staple length, fineness, moisture regain/content, tensile strength, and whiteness properties $[10]$.

2.2.2. Yarn Sample Collection and Sampling. There are eleven spinning mills that have ring spinning mills and processing $100 \%$ cotton carded yarns, from which five mills (45.45\% of the ring spinning mills) are selected for this study considering having wide count range, processing 100\% cotton, having a ring frame, and being active at the time of data collection periods. The yarn counts were selected based on the availability of yarn count in the selected mills. There were $15 \mathrm{Ne}, 20 \mathrm{Ne}, 25 \mathrm{Ne}, 30 \mathrm{Ne}, 35 \mathrm{Ne}$, and $40 \mathrm{~N}$ yarn counts, and from each types of yarn package, 20 carded spun ring yarn packages have been sampled. The yarn package collection method used was the random sampling method with probability in the sense that each member of the population has a known nonzero probability of being selected.

2.2.3. Yarn Testing. Before conducting yarn property testing, the yarn samples were conditioned at $65 \%$ relative humidity and $20^{\circ} \mathrm{C}$ temperature as stated in ES ISO 139 standard [11]. The yarn CVm (coefficient of variation in mass), hardness, neps, thin places, and thick places characteristics were determined using USTER tester 5 [12]. Ten tests from each package were conducted for yarn evenness and imperfections according to the ASTM D1425 test method [13]. The yarn strength and elongation were determined by using a STATIMAT tensile strength tester. In total, 50 tests were performed for each sample for yarn strength and elongation as per ISO 2062 standard [14].

2.3. Data Analysis. To categorize the Ethiopian $100 \%$ cotton carded ring spun yarn quality, USTER statistics percentile (USP $^{\mathrm{TM}}$ 2018, version 1.4.1) application was used and to determine whether there was a significant difference between the same yarn counts produced from different spinning mills. The ANOVA test was conducted using SPSS version 25 statistical software. The analysis was conducted for yarn used for weaving application after same process selection which is cotton, $100 \%$, carded, ring yarn, and package form.

\section{Results and Discussion}

3.1. Yarn Evenness Property. The yarn evenness result revealed that mill B3 has better CVm (mean CVm of 16.293 and 15.237 for yarn count $19.8 \mathrm{Ne}$ and $20.3 \mathrm{Ne}$, respectively) as compared to others, as shown in Table 3 and Figure 1. The standard deviation also confirmed that $100 \%$ cotton yarn evenness of mill B3 showed less standard deviations. This may be because fibres used for mill B3 have good fineness and maturity properties, which is similar to the work of Faulkner et al., who analysed that fibre fineness and 
TABLE 1: Ethiopian spinning mills.

\begin{tabular}{|c|c|c|c|c|c|c|}
\hline \multirow{2}{*}{$\begin{array}{l}\text { Ethiopian } \\
\text { spinning mill }\end{array}$} & \multirow{2}{*}{$\begin{array}{l}\text { Raw material } \\
\quad \text { (fibres) }\end{array}$} & \multicolumn{2}{|c|}{ Spinning machines } & \multirow[b]{2}{*}{ Capacity } & \multirow{2}{*}{$\begin{array}{c}\text { Yarn count range } \\
\text { produced }(\mathrm{Ne}) \text { by ring } \\
\text { spinning }\end{array}$} & \multirow[b]{2}{*}{ Remark } \\
\hline & & Ring frame & Open end & & & \\
\hline 1 & $100 \%$ cotton & $\begin{array}{l}15 \text { ring }(18000 \\
\text { spindles) }\end{array}$ & $\begin{array}{l}11 \text { open end } \\
(2640 \text { rotors })\end{array}$ & $\begin{array}{c}6,825,000 \mathrm{Kg} / \\
\text { year }\end{array}$ & $18-60$ & \\
\hline 2 & $100 \%$ cotton & 13200 spindles & & $\begin{array}{l}10 \text { ton, } \mathrm{Kg} / \\
\text { day }\end{array}$ & $10-40$ & \\
\hline 3 & $100 \%$ cotton & $\begin{array}{l}8 \text { ring (2204 } \\
\text { spindles) }\end{array}$ & $\begin{array}{l}4 \text { rotor; } 320 \\
\text { rotors/ } \\
\text { machines }\end{array}$ & 10.7 & $6-60$ & \\
\hline 4 & $100 \%$ cotton & $\begin{array}{l}5 \text { ring }(6000 \\
\text { spindles })\end{array}$ & $\begin{array}{l}6 \text { open end } \\
\text { ( } 2400 \text { rotors })\end{array}$ & 15 ton $\mathrm{Kg}$ /day & $20-40$ & \\
\hline 5 & $100 \%$ cotton & 10 rings & 2400 rotors & 8000 ton/year & $20-60$ & \\
\hline 6 & $100 \%$ cotton & $\begin{array}{l}10 \text { ring (12000 } \\
\text { spindles) }\end{array}$ & $\begin{array}{l}2 \text { open end ( } 480 \\
\text { rotors) }\end{array}$ & 1872 ton/year & $16-40$ & \\
\hline 7 & $\begin{array}{l}\text { Cotton and } \\
\text { polyester }\end{array}$ & $\begin{array}{l}25 \mathrm{rings} \\
600 \mathrm{spdl} / \mathrm{ring}\end{array}$ & 6 open end & 1300 ton/year & $21-60 \mathrm{Ne}$ & Mostly $40 \mathrm{Ne}$ \\
\hline 8 & $100 \%$ cotton & $\begin{array}{c}5 \text { rings } \\
\text { (5000 spdls) }\end{array}$ & - & 900 ton/year & $6-40$ & Average 21 \\
\hline 9 & Cotton yarn & (10 & Carded rotor & 840 ton/year & & $\begin{array}{l}\text { Not having ring } \\
\text { spinning }\end{array}$ \\
\hline 10 & Cotton & Ring & Open end & 5616 ton/year & & $\begin{array}{c}\text { Not manufactured } \\
\text { now }\end{array}$ \\
\hline 11 & $100 \%$ cotton & - & $\begin{array}{l}3 \text { open end } \\
(1440 \text { rotors })\end{array}$ & 4032 ton/year & $6-30$ & Not having ring \\
\hline 12 & Cotton and acrylic & & Worsted & 9000 ton/year & & $\begin{array}{c}\text { Not manufactured } \\
\text { now }\end{array}$ \\
\hline 13 & $\begin{array}{l}\text { Cotton and } \\
\text { polyester }\end{array}$ & Ring spun & - & 3600 ton/year & & $\begin{array}{l}\text { Texturing and } \\
\text { blending in yarn form }\end{array}$ \\
\hline 14 & $\begin{array}{l}\text { Cotton, acrylic, } \\
\text { viscose, and wool }\end{array}$ & 40 rings & - & 2121 ton/year & $10-40$ & \\
\hline 15 & $100 \%$ cotton & - & 1440 rotors & 2300 ton/year & $6-24$ & Not having ring \\
\hline 16 & Wool & - & & 600 ton/year & & Not cotton \\
\hline 17 & Nylon & 15120 spindles & 2400 rotors & $\begin{array}{c}7000000 \mathrm{Kg} / \\
\text { year }\end{array}$ & & Not cotton \\
\hline 18 & Regenerated yarn & - & Open end & 2184 ton/year & & Not cotton \\
\hline
\end{tabular}

sufficient strength are crucial to produce high-quality ring spun yarns to endure spinning preparations and spinning processing [9]. Next to mill B3, CVm of mill A4 with $32 \mathrm{Ne}$ yarn count and mill K3 with $15.28 \mathrm{Ne}$ yarn count had moderate evenness and a mean CVm of 17.184 and 17.277, respectively. On the other hand, mill A2 with yarn count $32.85 \mathrm{Ne}$, mill K3 with yarn count $32.85 \mathrm{Ne}$, and mill A0 with a yarn count of $21.6 \mathrm{Ne}$ and $30 \mathrm{Ne}$ have low yarn evenness as compared to others.

3.2. Yarn Imperfection Properties. Yarn imperfections are yarn thin places, thick places, and neps which are decisive factors on the external appearance of yarns and the products obtained from them. USTER tester 5 allows $30 \%,-40 \%,-50 \%$, and $-60 \%$ sensitivity thresholds for thin places, $+35 \%,+50 \%,+70 \%$, and $+100 \%$ sensitivity thresholds for thick places, and $+140 \%$, $+200 \%$, $+280 \%$, and $+400 \%$ sensitivity thresholds for neps. Standard setting values taken for test are $-50 \%,+50 \%$, and $+200 \%$ for thin places, thick places, and neps, respectively, by UUSTER statistics reference values. Yarn imperfections are normally assessed by measuring the number of thin places, thick places, and neps per kilometer of yarn. Yarn imperfections are caused by defects in materials (fibre) or improper machine settings. A reliable analysis of these "imperfections," therefore, will not only make possible the achievement of optimum conditions during the various manufacturing processes but also can provide some reference to the quality of the raw material used.

As illustrated in Figure 2 and Table 4, the yarn from mill A0 $(30 \mathrm{Ne})$ scored the highest number of thin place per kilometer with mean value 1112.6 , and the lowest thin place is found at mill B3 $(20.3 \mathrm{Ne})$ with mean value 2 . Therefore, mill B3 with yarn count $20.3 \mathrm{Ne}$ is producing excellent yarn in terms of thin place.

Mill B3 with yarn count $38.2 \mathrm{Ne}$ and mill A0 with yarn count $30 \mathrm{Ne}$ have the greatest number of thick place per kilometer with mean of 1245.2 and 2213.8, respectively, as shown in Figure 3. In the same manner as thin and thick place, the neps of mill B3 of yarn count $38.2 \mathrm{Ne}$ and mill A0 of yarn count $30 \mathrm{Ne}$ exhibited the highest number of neps per kilometer (Figure 4), whereas mill B3 of yarn count $20.3 \mathrm{Ne}$ has the lowest neps per kilometer with mean of 244.4.

From evenness and imperfection results, we can observe that mill A0 of yarn count $30 \mathrm{Ne}$ has low evenness, high thick 
TABLE 2: Characteristics for cotton lint.

\begin{tabular}{|c|c|c|c|c|c|c|}
\hline Spinning mill code & Cotton origin & Lot number & $\mathrm{L}(\mathrm{mm})$ & Str (g/tex) & Micronaire & Mat ratio \\
\hline \multirow{12}{*}{ A0 } & \multirow{12}{*}{$\mathrm{Lu}$} & 19 & 25.75 & 25.08 & 4.39 & 0.85 \\
\hline & & 21 & 24.22 & 25.31 & 4.34 & 0.81 \\
\hline & & 22 & 25.57 & 24.44 & 4.28 & 0.84 \\
\hline & & 25 & 24.87 & 23.15 & 4.21 & 0.83 \\
\hline & & 26 & 22.92 & 19.99 & 4.16 & 0.82 \\
\hline & & 29 & 22.61 & 24.28 & 3.85 & 0.73 \\
\hline & & 31 & 24.20 & 20.81 & 4.05 & 0.80 \\
\hline & & 33 & 25.33 & 22.00 & 4.41 & 0.85 \\
\hline & & 35 & 24.26 & 23.02 & 4.27 & 0.77 \\
\hline & & 36 & 23.67 & 21.98 & 3.65 & 0.73 \\
\hline & & 37 & 23.39 & 23.56 & 4.28 & 0.82 \\
\hline & & Mean & 24.25 & 23.53 & 4.17 & 0.80 \\
\hline \multirow{3}{*}{ B3 } & \multirow{3}{*}{ W } & 39 & 21.7342 & 25.7 & 4.06 & 0.86 \\
\hline & & 64 & 23.4425 & 29.2 & 3.86 & 0.85 \\
\hline & & Mean & 22.666 & 27.45 & 3.96 & 0.855 \\
\hline \multirow{3}{*}{ A2 } & \multirow{3}{*}{ M } & 42 & 25.6576 & 28.6 & 4.03 & 0.85 \\
\hline & & 27 & 24.0448 & 29.8 & 3.96 & 0.85 \\
\hline & & Mean & 24.8467 & 29.2 & 3.995 & 0.85 \\
\hline \multirow{10}{*}{ K3 } & $M$ & 49 & 29.10 & 23.00 & 4.50 & \\
\hline & WE & 30 & 28.20 & 21.00 & 4.50 & 0.85 \\
\hline & $\mathrm{A} \mathrm{A}$ & 28 & 28.80 & 20.00 & 4.60 & 0.85 \\
\hline & $\mathrm{YO}$ & 44 & 28.70 & 20.00 & 4.50 & 0.85 \\
\hline & YO & 65 & 29.40 & 24.00 & 4.40 & 0.85 \\
\hline & YO & 69 & 28.80 & 21.0 & 4.30 & 0.85 \\
\hline & YO & 68 & 27.70 & 22.00 & 4.40 & 0.85 \\
\hline & YO & 72 & 29.30 & 23.00 & 4.50 & 0.85 \\
\hline & \multirow[t]{2}{*}{$\mathrm{Nh}$} & 19 & 29.30 & 23.00 & 4.50 & 0.85 \\
\hline & & Mean & 28.81 & 21.89 & 4.47 & 0.85 \\
\hline \multirow{5}{*}{ A 4} & \multirow{5}{*}{ A } & 4 & 29.12 & 22.4 & 4.24 & 0.85 \\
\hline & & 14 & 28.88 & 22.1 & 4.35 & 0.85 \\
\hline & & 21 & 29.40 & 23.2 & 4.28 & 0.84 \\
\hline & & 35 & 28.96 & 23.8 & 4.61 & 0.86 \\
\hline & & Mean & 29.09 & 22.87 & 4.37 & 0.85 \\
\hline
\end{tabular}

$\mathrm{L}=$ length, $\mathrm{Str}=$ strength, $\mathrm{SFC}=$ short fibre content, Mat = maturity.

TABle 3: Descriptive analysis of yarn evenness.

\begin{tabular}{|c|c|c|c|c|c|c|c|c|}
\hline Property & Mill code & Yarn count $(\mathrm{Ne})$ & $\mathrm{N}$ & Mean & Std. deviation & Std. error & Min. & Max. \\
\hline \multirow{13}{*}{$\mathrm{CVm}$} & \multirow{3}{*}{ B3 } & 19.8 & 10 & 16.293 & 0.6250 & 0.1977 & 15.24 & 17.06 \\
\hline & & 20.3 & 10 & 15.237 & 0.4679 & 0.1480 & 14.48 & 15.79 \\
\hline & & 38.2 & 10 & 20.552 & 0.3525 & 0.1115 & 19.76 & 20.91 \\
\hline & \multirow{3}{*}{ A2 } & 23.47 & 10 & 19.230 & 2.3547 & 0.7446 & 16.90 & 24.10 \\
\hline & & 32.85 & 10 & 20.164 & 1.7762 & 0.5617 & 17.58 & 22.69 \\
\hline & & 36.2 & 10 & 18.665 & 0.9124 & 0.2885 & 17.56 & 20.10 \\
\hline & \multirow{3}{*}{ K3 } & 15.28 & 10 & 17.277 & 0.7503 & 0.2373 & 16.54 & 18.67 \\
\hline & & 21.21 & 10 & 18.545 & 1.7500 & 0.5534 & 17.10 & 23.26 \\
\hline & & 32.85 & 10 & 19.651 & 0.5964 & 0.1886 & 18.93 & 20.68 \\
\hline & \multirow{2}{*}{ A0 } & 21.6 & 10 & 20.231 & 2.8038 & 0.8866 & 15.38 & 23.31 \\
\hline & & 30 & 10 & 24.812 & 0.7629 & 0.2412 & 24.08 & 26.66 \\
\hline & \multirow{2}{*}{$\mathrm{A} 4$} & 32 & 10 & 17.184 & 0.5417 & 0.1713 & 16.22 & 17.80 \\
\hline & & 40 & 10 & 20.057 & 0.7467 & 0.2361 & 19.36 & 21.56 \\
\hline
\end{tabular}

place, and high neps, whereas mill B3 of yarn count $20.3 \mathrm{Ne}$ has the lowest number of thin places, thick places, and neps with good evenness characteristics.

Table 5 shows ANOVA of evenness and imperfections of the same yarn count $(20 \mathrm{Ne}$ as nominal count) produced from mills $\mathrm{B} 3, \mathrm{~A} 2, \mathrm{~A} 0$, and $\mathrm{K} 3$. The results showed that yarns' CVm, thin places $(-50 \%)$, thick places $(+50 \%)$, and neps (200\%) properties are significantly different. This significance may most probably due to raw material difference and process errors.

3.3. Yarn Strength Properties. From Table 6 and Figure 5, it can be seen that the maximum tensile strength is for mill A2 


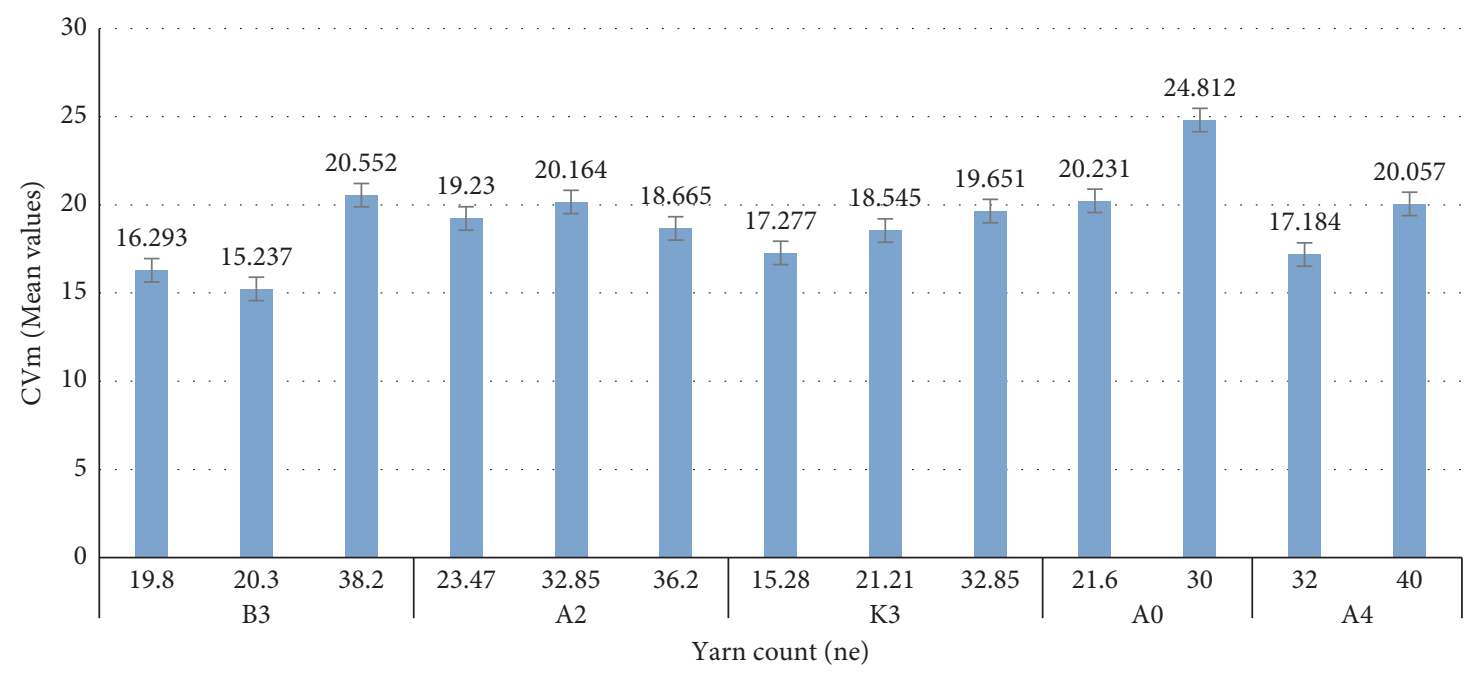

Mean

Figure 1: Yarn evennenes analysis.

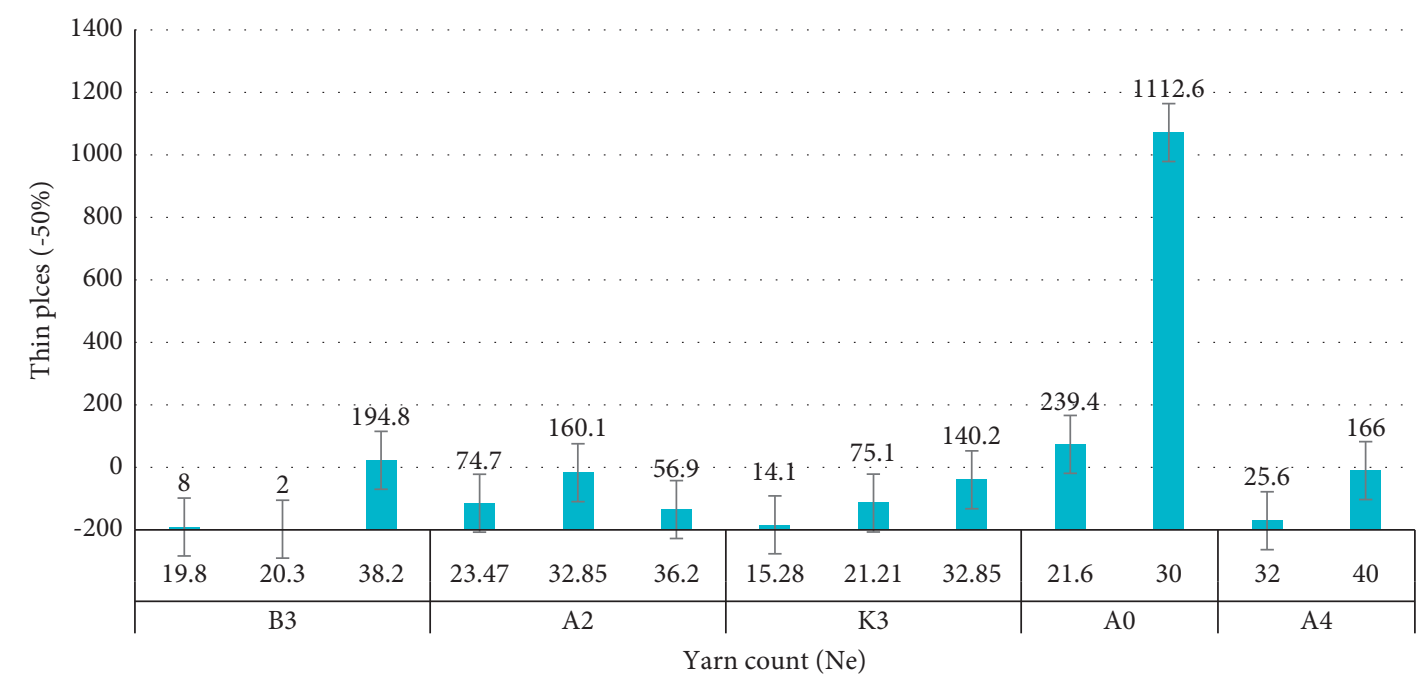

Figure 2: Yarn thin place (-50\%).

of yarn count $32.85 \mathrm{Ne}$ and $36.2 \mathrm{Ne}$ with a mean tensile strength of $18.87 \mathrm{cN} /$ tex and $19.32 \mathrm{cN} /$ tex, respectively, and the minimum is found at mill A0 of yarn count $30 \mathrm{Ne}$ and $21.6 \mathrm{Ne}$, mill A4 of yarn count $32 \mathrm{Ne}$, and mill A2 of yarn count $23.47 \mathrm{Ne}$. Taking only raw material as a factor, mill A2 used a good fibre quality (fibre strength, maturity, and fineness) as compared to others; in fact, other factors for yarn tensile strength are not known here. Figure 6 shows that the highest yarn elongation is found for mill A2 and the lowest yarn elongation is for mill A0.

The previous report showed the $\mathrm{CV}$ of tenacity for various yarns, and the best cotton yarns vary from about $4 \%$ for $6 \mathrm{Ne}$ carded ring yarn to about $9 \%$ at $50 \mathrm{Ne}$ count $(\approx 12$ tex $)$. The worst yarns have CVs of the order of $10 \%$. Combed cotton yarns have CVs varying from $4.5 \%$ at $15 \mathrm{Ne}$ count $(\approx 40$ tex $)$ to $12 \%$ at $120 \mathrm{Ne}$ count for the best yarns. The worst yarns vary from $8.5 \% \mathrm{CV}$ to $15 \% \mathrm{CV}$ for corresponding counts ( $\approx 5$ tex), and worsted yarns have high CVs of tenacity. It should be noted that the CVs of tenacity measured at higher testing speeds tend to be a little higher than those quoted [2].

For the yarn count $20 \mathrm{Ne}$, yarn tensile strengths and elongations were significantly different at a $P$ value of 0.001 (see Table 7), and $P$ value or sig. value is less than 0.05 .

\section{Ethiopian Cotton Yarn Quality Based on USTER Statistics 2018 Analysis}

Table 8 shows Ethiopian spinning mills' yarn quality level against USTER statistics percentile (USP) for weaving application. Actually, the USP value range can be between 5\% (the best possible) and 95\% (the worst possible). Since the raw material in a spinning mill account for $50-60 \%$ of the total manufacturing costs, it is important to set the quality characteristic limits, benchmarking for yarns, according to customer demands. In this point, 5\% USP for yarns means excellent in terms of yarn quality but also very expensive 
TABLE 4: Descriptive analysis of yarn imperfections.

\begin{tabular}{|c|c|c|c|c|c|c|c|c|}
\hline Property & Mill code & Yarn count $(\mathrm{Ne})$ & $\mathrm{N}$ & Mean & Std. deviation & Std. error & Min & Max \\
\hline \multirow{13}{*}{ Thin places $-50 \%$} & \multirow{3}{*}{ B3 } & 19.8 & 10 & 8.00 & 7.6012 & 2.4037 & 0.00 & 26.00 \\
\hline & & 20.3 & 10 & 2.00 & 1.8856 & 0.5963 & 0.00 & 6.00 \\
\hline & & 38.2 & 10 & 194.80 & 26.9683 & 8.5281 & 144.00 & 248.00 \\
\hline & \multirow{3}{*}{$\mathrm{A} 2$} & 23.47 & 10 & 74.70 & 161.7275 & 51.1427 & 10.00 & 534.00 \\
\hline & & 32.85 & 10 & 160.10 & 140.3776 & 44.3913 & 13.00 & 365.00 \\
\hline & & 36.2 & 10 & 56.90 & 48.9999 & 15.4951 & 16.00 & 160.00 \\
\hline & \multirow{3}{*}{$\mathrm{K} 3$} & 15.28 & 10 & 14.10 & 6.60724 & 2.0894 & 4.00 & 26.00 \\
\hline & & 21.21 & 10 & 75.10 & 161.6453 & 51.1167 & 10.00 & 534.00 \\
\hline & & 32.85 & 10 & 140.20 & 35.8881 & 11.34881 & 88.00 & 190.00 \\
\hline & \multirow{2}{*}{$\mathrm{A} 0$} & 21.6 & 10 & 239.40 & 179.40903 & 56.7341 & 0.00 & 506.00 \\
\hline & & 30 & 10 & 1112.60 & 215.7057 & 68.2121 & 844.00 & 1600.00 \\
\hline & \multirow{2}{*}{$\mathrm{A} 4$} & 32 & 10 & 25.60 & 16.2289 & 5.1320 & 9.00 & 63.00 \\
\hline & & 40 & 10 & 166.00 & 73.1832 & 23.1426 & 102.00 & 339.00 \\
\hline \multirow{13}{*}{ Thick places $+50 \%$} & \multirow{3}{*}{ B3 } & 19.8 & 10 & 357.40 & 104.3245 & 32.9903 & 212.00 & 568.00 \\
\hline & & 20.3 & 10 & 190.00 & 46.1303 & 14.5877 & 110.00 & 258.00 \\
\hline & & 38.2 & 10 & 1246.20 & 88.7015 & 28.0499 & 1052.00 & 1362.00 \\
\hline & \multirow{3}{*}{$\mathrm{A} 2$} & 23.47 & 10 & 758.90 & 383.8835 & 121.3946 & 485.00 & 1803.00 \\
\hline & & 32.85 & 10 & 997.00 & 216.9475 & 68.6048 & 742.00 & 1284.00 \\
\hline & & 36.2 & 10 & 827.60 & 174.9706 & 55.3306 & 583.00 & 1132.00 \\
\hline & \multirow{3}{*}{$\mathrm{K} 3$} & 15.28 & 10 & 520.10 & 155.0824 & 49.0414 & 363.00 & 814.00 \\
\hline & & 21.21 & 10 & 756.00 & 385.3907 & 121.8712 & 464.00 & 1803.00 \\
\hline & & 32.85 & 10 & 807.20 & 79.64616 & 25.1863 & 679.00 & 956.00 \\
\hline & \multirow{2}{*}{ A0 } & 21.6 & 10 & 1011.60 & 454.17354 & 143.6223 & 176.00 & 1606.00 \\
\hline & & 30 & 10 & 2213.80 & 251.07316 & 79.3963 & 1884.00 & 2746.00 \\
\hline & \multirow{2}{*}{ A4 } & 32 & 10 & 404.00 & 73.13762 & 23.1282 & 281.00 & 490.00 \\
\hline & & 40 & 10 & 893.90 & 100.25795 & 31.7044 & 798.00 & 1071.00 \\
\hline \multirow{13}{*}{ Neps $+200 \%$} & \multirow{3}{*}{ B3 } & 19.8 & 10 & 375.80 & 138.62323 & 43.8365 & 164.00 & 618.00 \\
\hline & & 20.3 & 10 & 244.40 & 52.04955 & 16.4595 & 166.00 & 312.00 \\
\hline & & 38.2 & 10 & 2122.20 & 90.86473 & 28.7340 & 2050.00 & 2354.00 \\
\hline & \multirow{3}{*}{$\mathrm{A} 2$} & 23.47 & 10 & 890.30 & 302.93235 & 95.7956 & 611.00 & 1523.00 \\
\hline & & 32.85 & 10 & 1567.90 & 267.69985 & 84.6541 & 1246.00 & 1958.00 \\
\hline & & 36.2 & 10 & 1277.30 & 190.97065 & 60.3902 & 924.00 & 1479.00 \\
\hline & \multirow{3}{*}{$\mathrm{K} 3$} & 15.28 & 10 & 751.50 & 187.74051 & 59.3688 & 412.00 & 1127.00 \\
\hline & & 21.21 & 10 & 896.90 & 298.22678 & 94.3076 & 611.00 & 1523.00 \\
\hline & & 32.85 & 10 & 1676.10 & 177.56404 & 56.15068 & 1451.00 & 1918.00 \\
\hline & \multirow{2}{*}{ A0 } & 21.6 & 10 & 922.60 & 327.07872 & 103.4314 & 258.00 & 1328.00 \\
\hline & & 30 & 10 & 3051.60 & 245.64256 & 77.6790 & 2734.00 & 3508.00 \\
\hline & \multirow{2}{*}{$\mathrm{A} 4$} & 32 & 10 & 1042.00 & 166.88319 & 52.7731 & 814.00 & 1319.00 \\
\hline & & 40 & 10 & 1676.00 & 138.00242 & 43.6402 & 1513.00 & 1877.00 \\
\hline
\end{tabular}

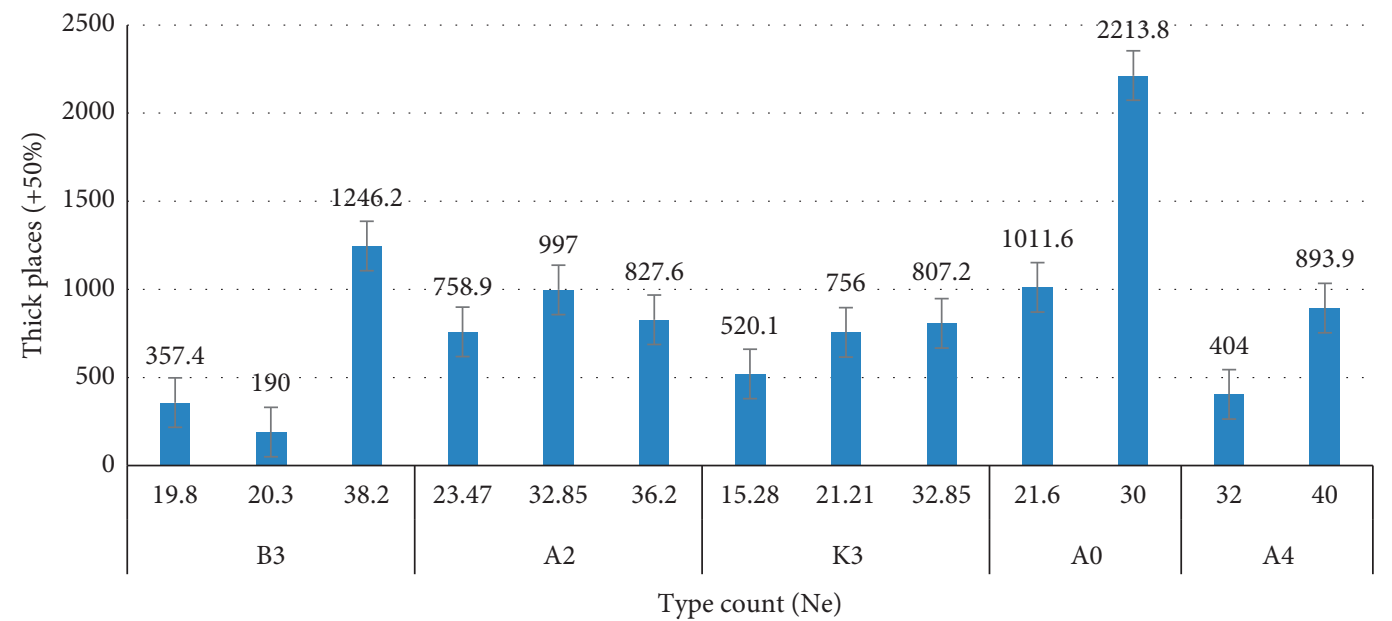

FIgURE 3: Yarn thick place (+50\%). 


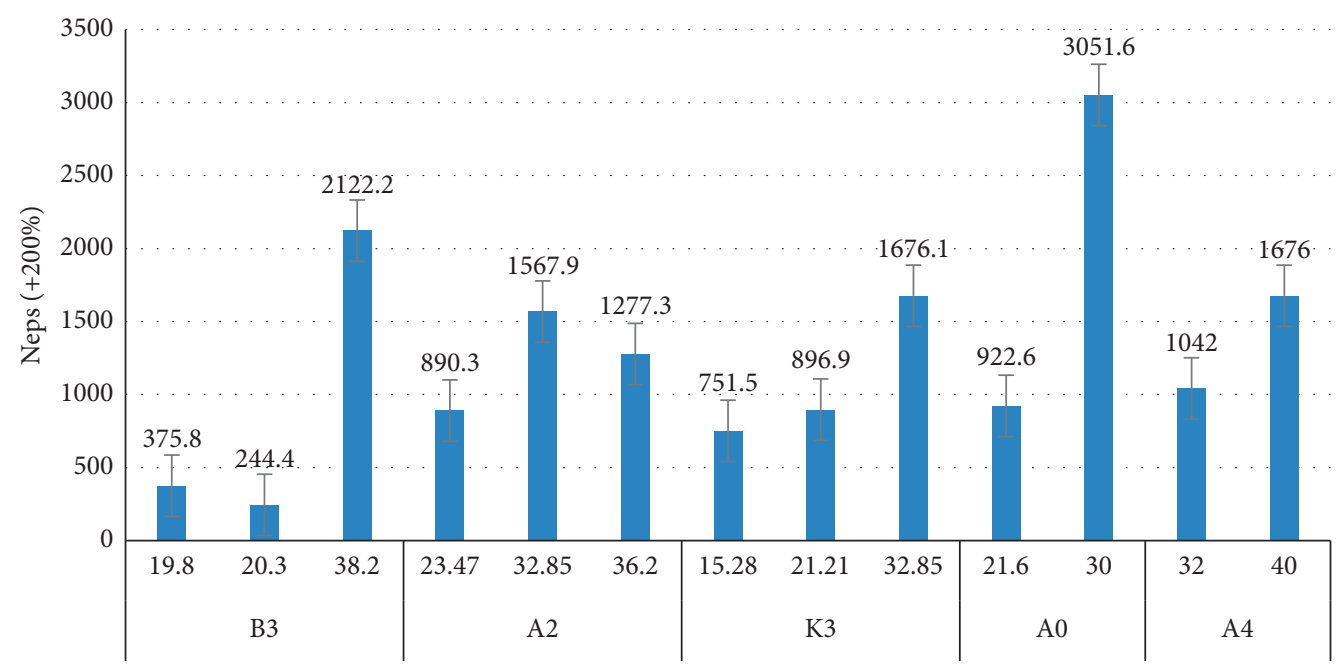

Type of count $(\mathrm{Ne})$

FigURE 4: Nep (+200\%) of different yarns.

TABLe 5: Analysis of variance results of yarn evenness and imperfection (20Ne nominal count).

\begin{tabular}{|c|c|c|c|c|c|c|}
\hline & & Sum of squares & $\mathrm{df}$ & Mean square & $\mathrm{F}$ & Sig. \\
\hline \multirow{2}{*}{$\mathrm{CVm}$} & Between groups & 686.641 & 2 & 57.220 & 31.598 & 0.000 \\
\hline & Within groups & 211.870 & 117 & 1.811 & & \\
\hline \multirow{2}{*}{ Thin places } & Between groups & 10251597.631 & 12 & 854299.803 & 69.046 & 0.000 \\
\hline & Within groups & 1447630.100 & 117 & 12372.907 & & \\
\hline \multirow{2}{*}{ Thick places } & Between groups & 30717111.000 & 12 & 2559759.250 & 46.898 & 0.000 \\
\hline & Within groups & 6386032.700 & 117 & 54581.476 & & \\
\hline \multirow{2}{*}{ Neps } & Between groups & 68952137.769 & 12 & 5746011.481 & 124.494 & 0.000 \\
\hline & Within groups & 5400117.800 & 117 & 46154.853 & & \\
\hline
\end{tabular}

TABLE 6: Decretive analysis of yarn strength and elongation.

\begin{tabular}{|c|c|c|c|c|c|c|c|c|}
\hline Yarn property & Mill code & Yarn count $(\mathrm{Ne})$ & $\mathrm{N}$ & Mean & Std. deviation & Std. error & Min. & Max. \\
\hline \multirow{13}{*}{ Tensile strength (cN/tex) } & \multirow{3}{*}{ B3 } & 19.8 & 50 & 13.32 & 0.8973 & 0.1269 & 11.61 & 15.51 \\
\hline & & 20.3 & 50 & 13.14 & 0.9415 & 0.1331 & 11.34 & 15.96 \\
\hline & & 38.2 & 50 & 12.75 & 1.2845 & 0.1817 & 10.40 & 15.07 \\
\hline & \multirow{3}{*}{ A2 } & 23.47 & 50 & 9.49 & 1.1225 & 0.1587 & 5.97 & 11.74 \\
\hline & & 32.85 & 50 & 18.87 & 2.3791 & 0.3365 & 13.20 & 25.78 \\
\hline & & 36.2 & 50 & 19.32 & 2.2138 & 0.3131 & 15.49 & 24.01 \\
\hline & \multirow{3}{*}{ K3 } & 15.28 & 50 & 13.38 & 0.8752 & 0.1238 & 11.26 & 16.20 \\
\hline & & 21.21 & 50 & 11.86 & 1.0619 & 0.1502 & 9.37 & 15.11 \\
\hline & & 32.85 & 50 & 12.99 & 1.3935 & 0.1971 & 9.39 & 15.67 \\
\hline & \multirow{2}{*}{ A0 } & 21.6 & 50 & 8.67 & 1.1427 & 0.1616 & 6.47 & 11.01 \\
\hline & & 30 & 50 & 7.61 & 0.8255 & 0.1168 & 6.14 & 9.54 \\
\hline & \multirow{2}{*}{ A4 } & 32 & 50 & 9.91 & 1.0815 & 0.1529 & 7.38 & 12.17 \\
\hline & & 40 & 50 & 12.23 & 1.1274 & 0.1594 & 9.65 & 15.03 \\
\hline \multirow{13}{*}{ Elongation (\%) } & \multirow{3}{*}{ B3 } & 19.8 & 50 & 6.07 & 0.3683 & 0.0521 & 5.33 & 7.12 \\
\hline & & 20.3 & 50 & 6.11 & 0.4052 & 0.0573 & 5.26 & 7.10 \\
\hline & & 38.2 & 50 & 5.17 & 0.4673 & 0.0661 & 4.24 & 6.12 \\
\hline & \multirow{3}{*}{ A2 } & 23.47 & 50 & 4.28 & 0.4441 & 0.0628 & 2.45 & 5.07 \\
\hline & & 32.85 & 50 & 8.54 & 0.7065 & 0.0999 & 6.46 & 9.95 \\
\hline & & 36.2 & 50 & 9.04 & 0.8804 & 0.1245 & 6.76 & 11.04 \\
\hline & \multirow{3}{*}{ K3 } & 15.28 & 50 & 6.62 & 0.3388 & 0.0479 & 5.77 & 7.50 \\
\hline & & 21.21 & 50 & 5.59 & 0.3722 & 0.0526 & 4.82 & 6.76 \\
\hline & & 32.85 & 50 & 5.08 & 0.4697 & 0.0664 & 3.95 & 6.04 \\
\hline & \multirow{2}{*}{ A0 } & 21.6 & 50 & 6.88 & 0.5431 & 0.0768 & 5.71 & 8.03 \\
\hline & & 30 & 50 & 5.90 & 0.4912 & 0.0695 & 4.85 & 6.99 \\
\hline & \multirow{2}{*}{ A4 } & 32 & 50 & 4.12 & 0.3137 & 0.0444 & 3.35 & 4.65 \\
\hline & & 40 & 50 & 5.21 & 0.4352 & 0.0615 & 4.07 & 5.99 \\
\hline
\end{tabular}




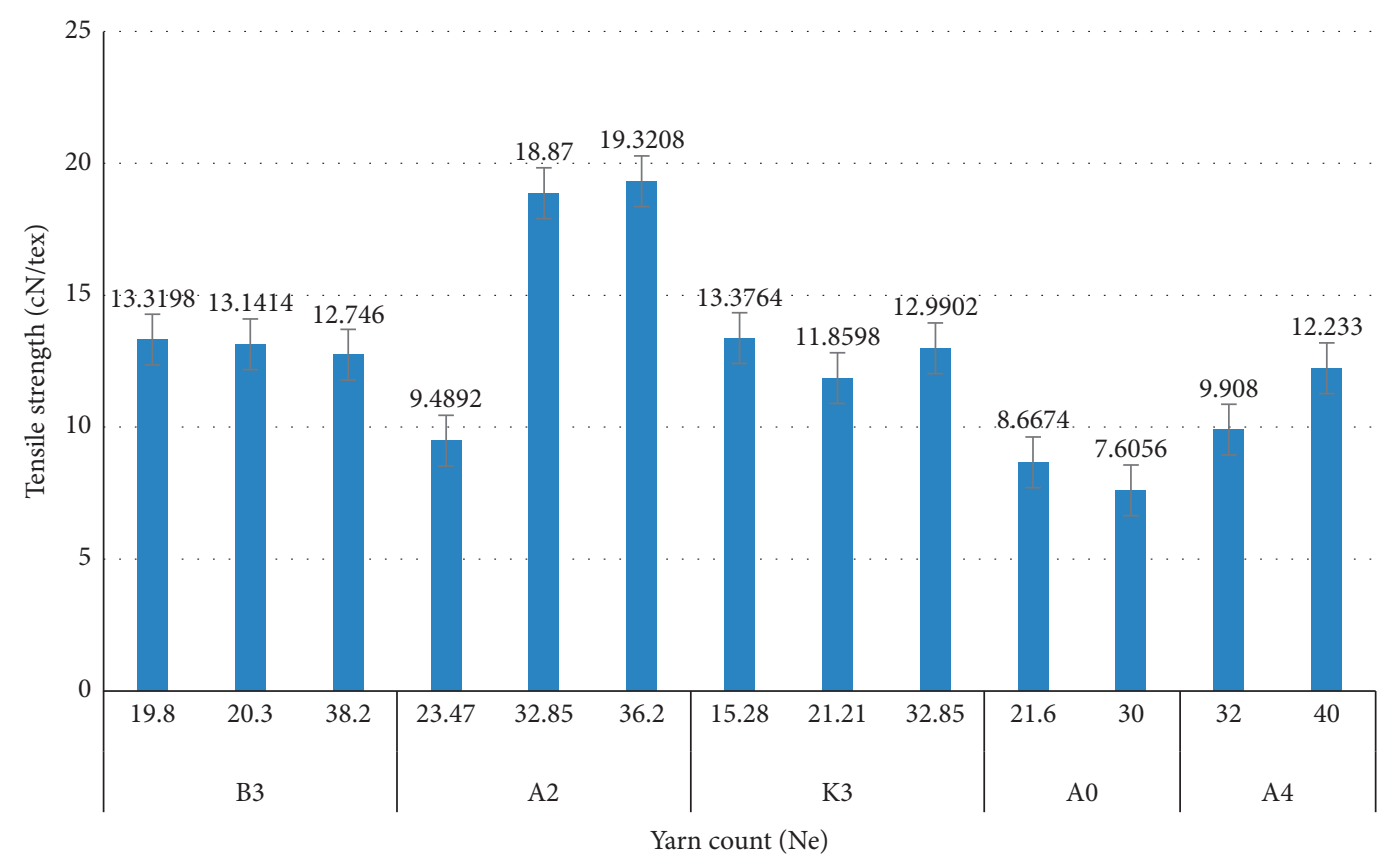

FIgURE 5: Yarn tensile strength.

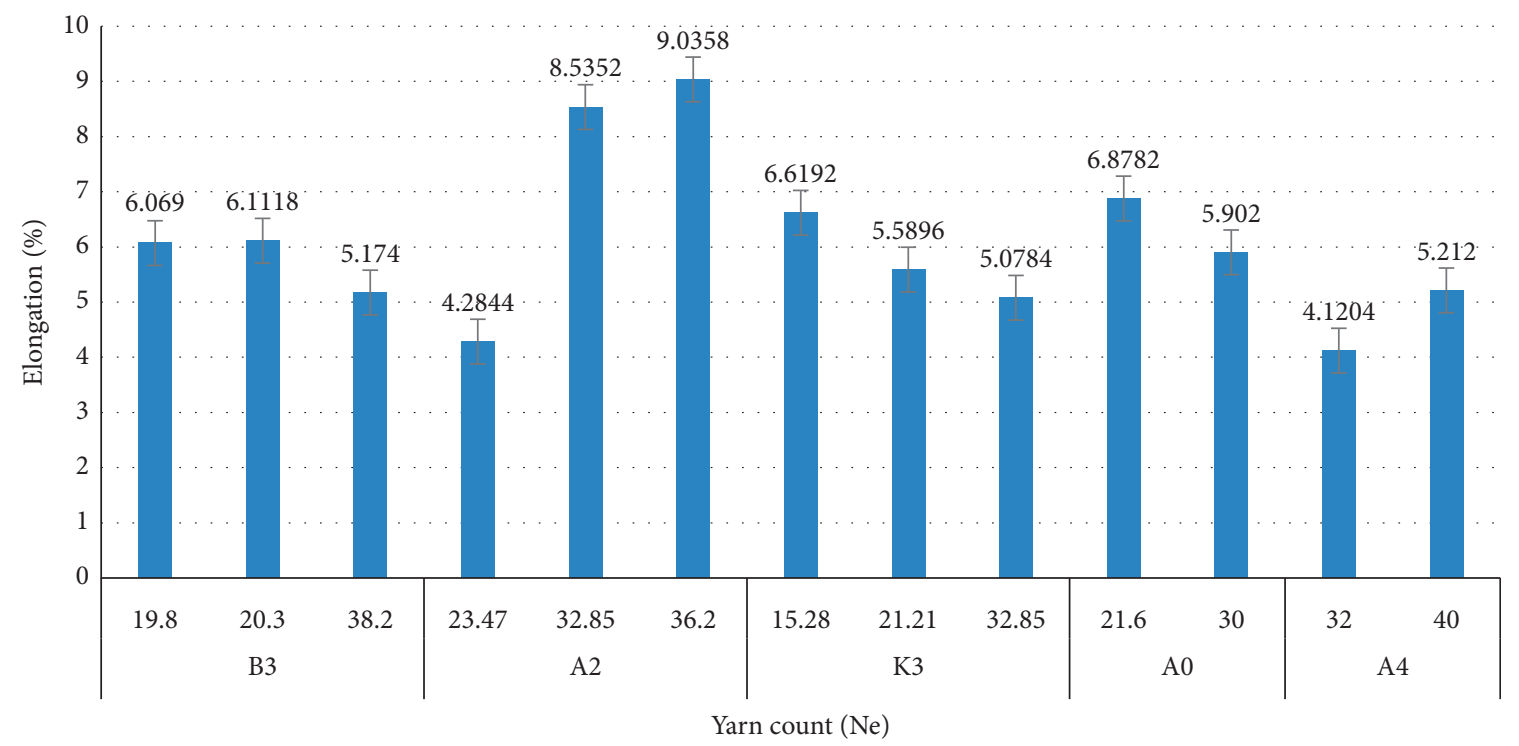

Figure 6: Yarn elongation.

TABLE 7: ANOVA results of yarn tensile and elongation for $20 \mathrm{Ne}$ yarns.

\begin{tabular}{lccccc}
\hline & & Sum of squares & df & Mean square & F \\
\multirow{2}{*}{ Tensile } & Between groups & 7203.992 & 2 & 600.333 & 333.149 \\
& Within groups & 1147.869 & 637 & 1.802 & 0.000 \\
\hline \multirow{2}{*}{ Elongation } & Between groups & 1279.669 & 2 & 106.639 & 421.680 \\
& Within groups & 161.092 & 637 & .253 & 0.000 \\
& & & \\
\hline
\end{tabular}

ones. As it can be seen in Table 8, USTER statistics percentile has 6 quality levels such as $\leq 5,6-25,26-50,51-75,76-95$, and $\geq 95 \%$. Based on this, the yarn evenness of mill B3 cotton yarn falls in the moderate UUSTER quality level which is $73 \%, 46 \%$, and $34 \%$ USP for yarn count $19.8 \mathrm{Ne}, 20.3 \mathrm{Ne}$, and $38.2 \mathrm{Ne}$, respectively. This means that $73 \%, 46 \%$, and $34 \%$ of the world production of these particular yarns $(19.8 \mathrm{Ne}$, 20.3 Ne, and $38.2 \mathrm{Ne}$ ) had a CVm value of $16.2,15.2$, and 20.5, respectively.

As evident from Table 8, except mill A2 of yarn count $32.85 \mathrm{Ne}$ and $36.2 \mathrm{Ne}$, the remaining spinners' yarn strength was found to be above 95\% USP. This indicates that globally, 
TABLE 8: USP Analysis of cotton yarns for weaving application.

\begin{tabular}{|c|c|c|c|c|c|c|c|c|}
\hline \multirow{3}{*}{ Mill Code } & \multirow{3}{*}{$\begin{array}{c}\text { Yarn } \\
\text { Count } \\
(\mathrm{Ne})\end{array}$} & \multicolumn{7}{|c|}{ USPTM } \\
\hline & & \multicolumn{2}{|c|}{$\leq 5 \%$} & \multicolumn{2}{|c|}{$26-50 \%$} & $51-75 \%$ & 76-95\% & $>95 \%$ \\
\hline & & $\begin{array}{c}\mathrm{CVm} \\
(\%)\end{array}$ & Thin $-50 \%$ & $\begin{array}{l}\text { Thick } \\
+50 \%\end{array}$ & $\begin{array}{l}\text { Neps } \\
+200 \%\end{array}$ & $\mathrm{H}$ & $\begin{array}{l}\text { Tenacity } \\
\text { (cN/tex) }\end{array}$ & $\begin{array}{c}\text { Elongation } \\
(\%)\end{array}$ \\
\hline \multirow{3}{*}{ B3 } & 19.8 & 73 & 50 & 85 & 74 & 93 & $>95$ & 12 \\
\hline & 20.3 & 46 & 10 & 58 & 54 & $>95$ & $>95$ & 39 \\
\hline & 38.2 & 34 & $>95$ & $>95$ & $>95$ & 67 & $>95$ & 6 \\
\hline \multirow{3}{*}{ K3 } & 15.28 & $>95$ & 81 & $>95$ & $>95$ & 86 & $>95$ & 24 \\
\hline & 21.21 & $>95$ & $>95$ & $>95$ & $>95$ & 63 & $>95$ & 68 \\
\hline & 32.85 & $>95$ & $>95$ & $>95$ & $>95$ & 81 & $>95$ & 69 \\
\hline \multirow{3}{*}{ A2 } & 23.47 & $>95$ & $>95$ & $>95$ & $>95$ & 81 & $>95$ & $>95$ \\
\hline & 32.85 & $>95$ & $>95$ & $>95$ & 93 & 81 & $\leq 5$ & $\leq 5$ \\
\hline & 36.2 & 93 & 83 & $>95$ & 78 & 67 & $\leq 5$ & $\leq 5$ \\
\hline \multirow{2}{*}{ A0 } & 21.6 & $>95$ & $>95$ & $>95$ & $>95$ & $>95$ & $>95$ & 7 \\
\hline & 30 & $>95$ & $>95$ & $>95$ & $>95$ & $>95$ & $>95$ & 29 \\
\hline \multirow{2}{*}{ A4 } & 32 & 72 & 62 & 72 & 79 & 94 & $>95$ & $>95$ \\
\hline & 40 & $>95$ & $>95$ & $>95$ & 81 & 73 & $>95$ & 52 \\
\hline
\end{tabular}

5\% mills are producing yarn with cotton yarn strength similar to that of mill A2 $(32.85 \mathrm{Ne}$ and $36.2 \mathrm{Ne})$, which is excellent yarn quality in terms of yarn strength.

\section{Conclusions}

Most of the studied spinning mills had low overall yarn properties. The statistical analysis showed that mill B3 $(20.3 \mathrm{Ne})$, A4 $(32 \mathrm{Ne})$, and A2 (36.2 Ne) cotton yarns had slightly better quality, respectively. The yarn tenacity and extension of mill A2 of yarn count $32.85 \mathrm{Ne}$ and $36.2 \mathrm{Ne}$ had fallen under $5 \%$ of USTER statistics percentile (USP 2018) which indicates higher yarn strength. In general, we can conclude that, in this particular study period from studied spinning mills, $61.5 \%$ of textile cotton yarn CVm and thin places (-50\%) falls at above $95 \%$ and $15 \%$ spinning mill's yarn tenacity falls at less than 5\% of USTER statistical percentile. Generally, authors advise that there must be an investigation or research starting from the raw material(fibre) to the process to know the causes $e$ and spin yarn of better quality.

\section{Data Availability}

All data are included in the manuscript.

\section{Conflicts of Interest}

The authors declare no conflicts of interest.

\section{References}

[1] T. Addis, A. Kachi, and J. Wang, "A review of current state and future directions of cotton production in Ethiopia," Cogent Food \& Agriculture, vol. 7, no. 1, Article ID 1880533, 2021.
[2] P. R. Lord, "Quality and quality control," in Handbook of Yarn Production, P. R. Lord, Ed., Woodhead Publishing, Sawston, UK, pp. 276-300, 2003.

[3] B. Wagaye, "Aspects of productivity in cotton spinning," International Journal on Textile Engineering and Processes, vol. 5, pp. 2395-3578, 2020.

[4] Ethiopian Investment Commission, Investment Opportunity Profile for Cotton Spinning Mill in Ethiopia, Ethiopian Investment Commission, Addis Ababa, Ethiopia, 2014.

[5] L. Hunter, "Testing cotton yarns and fabrics," in Cotton, S. Gordon and Y. L. Hsieh, Eds., Woodhead Publishing, Sawston, UK, pp. 381-424, 2007.

[6] M. E. Üreyen and H. Kadoğlu, "The prediction of cotton ring yarn properties from AFIS fibre properties by using linear regression models," Fibres \& Textiles in Eastern Europe, vol. 15, no. 4, 2007.

[7] R. Furferi, L. Governi, and Y. Volpe, "A novel method for ring spinning performance evaluation based on Computer Aided analysis of yarn geometry," International Journal of Mechanics, vol. 6, no. 4, 2012.

[8] Uster, Uster Statistics, Uster, Uster, Switzerland, 2018.

[9] W. B. Faulkner, J. Wanjura, and R. Boman, "Relationships of cotton fiber properties to ring-spun yarn quality on selected High Plains cottons," Textile Research Journal, vol. 82, no. 4, pp. 400-414, 2012.

[10] A. Khatri, I. A. Sahito, F. Ahmed, and I. Khatri, "Fiber quality evaluation of Pakistan's locally developed cotton varieties for yarn manufacturing," Journal of Natural Fibers, vol. 15, no. 3, pp. 344-352, 2018.

[11] ISO139, Textiles-Standard Atmospheres for Conditioning and Testing, ISO, Geneva, Switzerland, 2005.

[12] Uster, Uster Tester 5-S800 Application Report, Uster, Uster, Switzerland, 2009.

[13] ASTMD1425, Standard Test Method for Evenness of Textile Strands Using Capacitance Testing Equipment, ASTMD, West Conshohocken, PA, USA, 2020.

[14] ISO2062, Textiles-Yarns from Packages-Determination of Single-End Breaking Force and Elongation at Break Using Constant Rate of Extension (CRE) Tester, ISO, Geneva, Switzerland, 2020. 